Historic, Archive Document

Do not assume content reflects current scientific knowledge, policies, or practices. 


\title{
1910-1911
}

\section{WHOLESALE CATALOGUE AND PRICE LIST}

\section{GRAY'S NURSERY PEKIN, INDIANA.}

\author{
R. D. NO. 13
}

Fruit Trees, Berry Plants, Cuttings, Etc.

THE HALF-PRICE NURSERY.

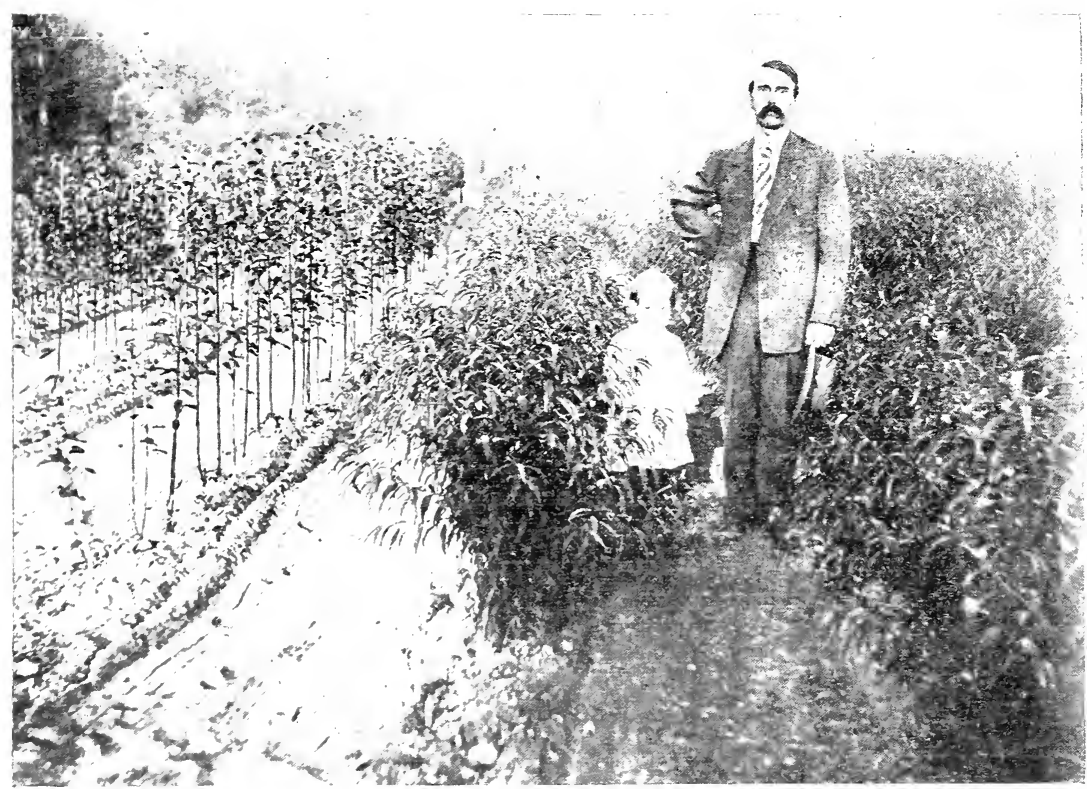

ALVIA G. GRAY AMONG HIS TREES.

Our Specialties are Choice Blackberry Plants and Root Cuttings, Raspberry and Strawberry Plants of all Standard Varieties.

Samples of our Plants and Trees may be seen at our Branch Packing Ground corner of Main and Market streets, BORDEN, IND., on C. I. \& L. R. R.

TWENTY YEARS EXPERIENCE WITH PLANTS AND TREES. 


\section{SMALL FRUITS}

RASPBERRY The Hoosier Black Cap. This grand berry stands first, not only in our list, but also as a money maker. It has no equal as to productiveness, hardiness and healthy growth of cane and size, color and flavor of fruit. "Berries sell at $\$ 1.0$ J a gallon on the average; it is " a pocketbook filler." All of the leading nurseries are listing it and it is classed far ahead of Cumberland by our best commercial growers. If you want additional proofs, write us.

Strong plants, $\$ 1.00$ per dozen, prepaid. $\$ 3.00$ per 100 by express; $\$ 8.00$ per $500 ; \$ 15.00$ per 1000 . Try the HOOSIER!

CUMBERLAND BLACK CAP, $\$ 1.25$ per $100 ; \$ 6.00$ per $500 ; \$ 10.00$ per 1000 .

KANSAS BLACK CAP, $\$ 8.50$ per 1000 .

PLUM FARMER $\$ 10.00$ per 1000.

RED RASPBERRY - RED ROSE a beautiful bright red, extra large and solid, does not crumble or drop from the vines, good grower, very productive and as hardy as an oak. Not a trace of the purplish color that we find in a great many red raspberries. The best red for market purposes. Resembles Louden, but decidedly advanced on that grand berry. per 1000 .

Price $\$ 1.00$ dozen, prepaid; $\$ 3.00$ per 100 by express; $\$ 8.00$ per $500 ; \$ 15.00$

LOUDEN RED $-\$ 1.25$ per $100 ; \$ 5.00$ per $500 ; \$ 8.00$ per 1000 .

MILLER AND EARLY KING REDS, same price as Louden.

GIBRALTAR - The famous, new, iron clad, Canadian Black Cap Raspberry.

ST. REGIS-The great, new, everbearing Red Raspberry.

We offer extra strong plants of either above varieties at 75 cents per dozen; $\$ 1.50$ per $50 ; \$ 2.50$ per 100 .

\section{BLACKBERRIES}

GRAY'S PERFECTION-Perfectly hardy, even at extreme North. An extra rank grower of strong canes that stand up well, fruit.jet black and glossy, very large, oblong shape, very firm, even when fully ripe; the berries hang in great clusters, and have the excellent flavor of the Wilson, but a decided improvment over all other varieties, having withstood 35 below zero. Season medium to late.

Price $\$ 1.00$ per dozen; $\$ 3.00$ per $100 ; \$ 8.00$ per $500 ; \$ 15.00$ per 1000 .

EARLY HARVEST blackberry plants, select grade, at $\$ 5.00$ per 1000 .

SNYDER, No. 1 plants at $\$ 6.00$ per 1000 .

MERSEREAU, WILSON AND LOVETT'S BEST, blackberry plants, best grade, at $\$ 8.00$ per 1000 .

\section{Select Blackberry Root Cuttings}

These are standard length, recalloused, hand-graded root cuttings, put up in the very best shape, and we are selling hundreds of thousands to the leading nurseries and to the most progressive commercial growers throughout the United States, who prefer them to ordinary plants.

Prices-Early Harvest, at $\$ 1.00$ per 1000 ; Snyder, at $\$ 1.50$ per 1000 ; Mersereau, Wilson and Lovett's Best, at $\$ 2.00$ per 1000 ; Gray's Perfection, at $\$ 2.50$ per 1000 . 


\section{Strawberry Plants}

We desire to call special attention to the fact that all of our plants and trees as well, are grown on new soil, admirably well suited to the production of a splendid root system, and our plants, strawberry especially, have large, strong crowns and that excellent root system so necessary to start plants to growing as soon as set in their new home.

OUR DOLLAR MARK STRAWBERRY easily takes first place in the ranks of our best market berries. The plant is large and stocky, an excellent grower and plant maker, entirely free from rust. It is a perfect bloomer and its long, vigorous roots renders it resistant of both drouth and freezing, berries very large and perfectly even in shape and holds out perfect to end of season; NO BUTTONS.

Outclasses Gandy as a solid shipper and will produce four times as many berries per acre; it is the least injured by frost and the best and most profitable berry we have ever grown; by all means plant some Dollar Mark.

Price.......... Owing to our large stock of plants and that we wish to bring it to the notice of the greatest possible number of fruit growers, we are for a limited time offering select plants at the greatly reduced price of $\$ 1.00$ per $100 ; \$ 3.00$ per $500 ; \$ 5.00$ per 1000 .

WARFIELD, (Imp.) at $\$ 2.75$ per 1000 .

SENATOR DUNLAP, (Per.) at $\$ 2.75$ per 1000.

AROMA, (Per.) at $\$ 3.00$ per 1000 .

HAVERLAND, (Imp.) at $\$ 3.00$ per 1000 .

NORWOOD, at $\$ 1.50$ per 100 .

EA. OZARK, $\$ 1.00$ per 100.

\section{Huckleberry or Blueberry}

GIANT BUSH is an upright grower, perfectly hardy everywhere, easy to cultivate and immensely productive, of the most lucious and highly flavored berries in existence; it is attracting a great deal of attention throughout the whole country at present and nothing in either large or small fruit comes anyways near equaling it as a dessert or for pies, preserves, canning or eating out of hand. No fruit farm or garden is complete without at least a few rows of blue berries.

NOTE-Do not confuse this berry with the worthless "garden huckleberry or wonderberry." Ours is the Blueberry of commerce, always quoted in market reports at $50 \mathrm{c}$ to $75 \mathrm{c}$ per gallon.

Strong plants $\$ 1.00$ per dozen; $\$ 3.00$ per $100 ; \$ 6.00$ per $500 ; \$ 10.00$ per 1000 .

GOOSEBERRY-Downing and Houghton at 15 cents each; $\$ 6.00$ per 50 ; $\$ 10.00$ per 100 .

CURRANTS-Fays, Red Cross, Pomona, Perfection, White Grape and Lee's Black; 15 cents each; $\$ 6.00$ per $50 ; \$ 10.00$ per 100 .

GRAPE-Concord, Deleware, Woodruff, Agawam, Niagara, Etc., at 10 cents each; $\$ 1.00$ per dozen; $\$ 6.00$ per 100 . 

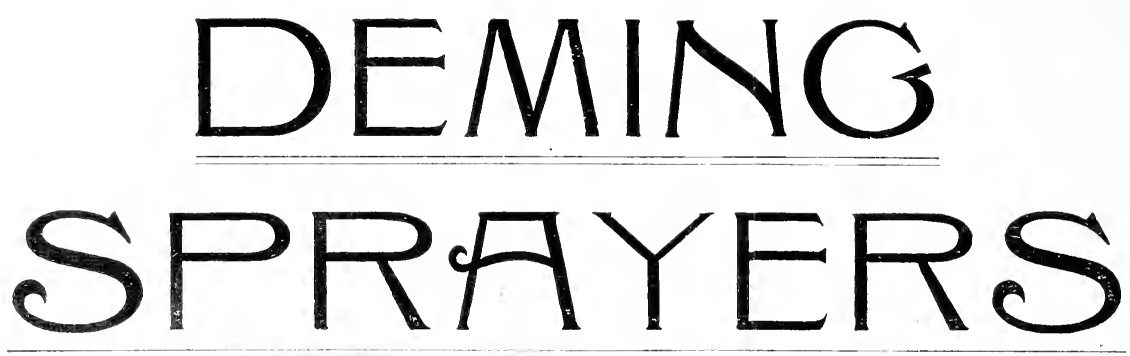

\section{For All Spraying Conditions}

Two dozen styles of Spray Pumps from the Small Bucket and Knapsack Sprayers to the Barrel, Tank and Power Sprayers for Extensive Orchard Operations. Seven styles of Spraying Nozzles and a Score of Spraying Appliances.

\section{Deming Sprayers are Practical}

Pumps have Brass Working Parts. We make the Patent Bordeaux, Demorel and Simplex Nozzels. Used and Recommended by leading fruit growers and Agricultural Experiment Stations. They are known as "The World's Best."

\section{A few DEMING SPRAYERS are illustrated below and on the following page.}

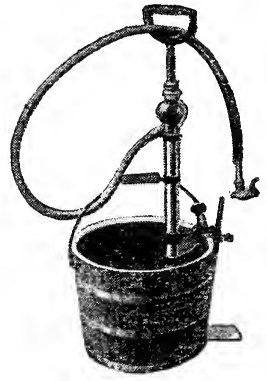

Fig. 689

The "Perfect Success" for "Garden and Greenhouse.

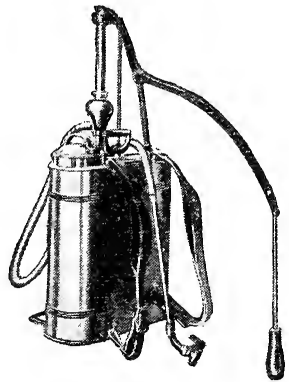

Fig. 675

The “"Success" Knapsack for Garden and Vineyard.

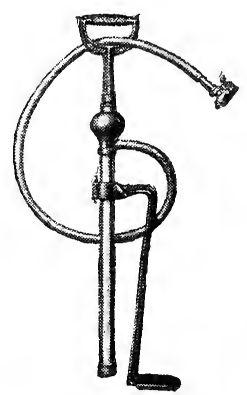

Fig. 659

The "Success" for Garden, Etc. 


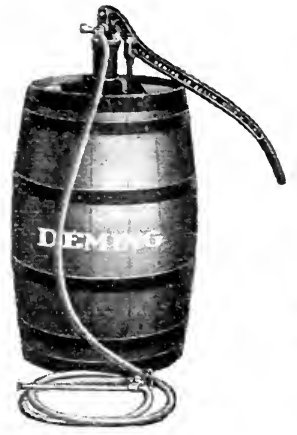

Fig. 645

The "Century" for Orchard and Field.

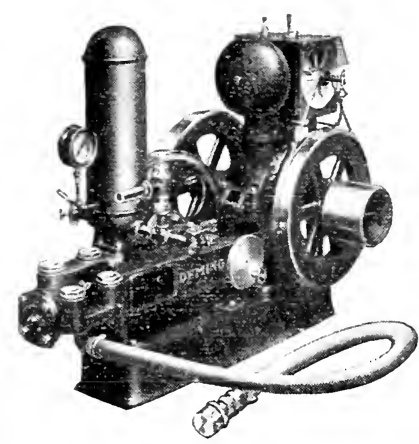

Fig. 656

The "Premier" Power Sprayer for large operation.

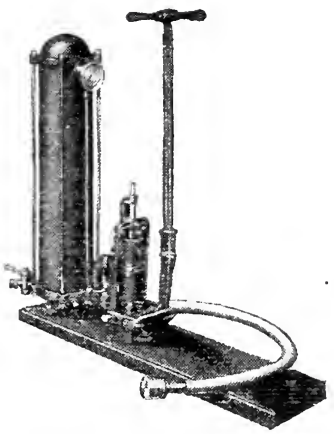

Fig. 633

The "Samson" a Powerful Orchard Sprayer.

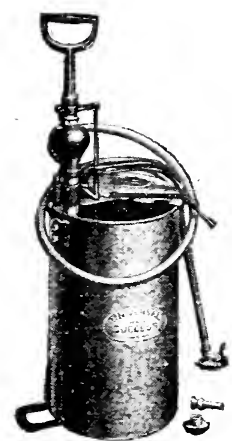

Fig. 662

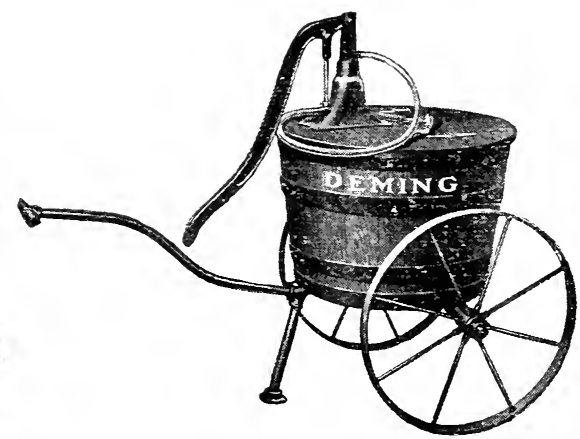

Fig. 651

The "Gardeners' Choice" for Garden and Orchard.

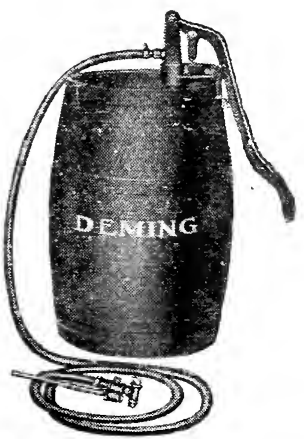

Fig. 632

The "Captain" medium price Orchard Sprayer.

in One") for Spraying, Whitewashing, Fire Protection, etc.

\section{THE DEMING CO.}

Manufacturers of

\section{Hand and Power Pumps for all Uses SALEM, OHIO}

Sold by dealers generally_-Wholesale distributing agencies in the principal cities. Illustrated catalogue with Spraying chart with formulas and directions on request.

The publisher of this catalogue uses and endorses the Deming sprayers. 
PERSIMMONS-GOLDD DROP, large golden yellow, very productive, comes into bearing young, fruit very sweet and firm, a good shipper and the best for market and all other purposes.

Price-35 cents each, three for $\$ 1.00$; $\$ 3.50$ per dozen.

FILBERTS-Jumbo or Mammoth Cluster, large and early, nuts part freely from the pod, the best for all sections, being entirely hardy, easy to cultivate and immensely productive and profitable.

Strong plants 10 cents each, $\$ 1.00$ per dozen; $\$ 7.50$ per 100 .

BLACK WALNUT-Very valuable for both nuts and timber; productive and comes into bearing young, a thrifty and symmetrical grower.

Price-First-class trees 20 cents each; $\$ 2.00$ per dozen; $\$ 15.00$ per 100 .

CHESTNUT-American Sweet, the most valuable chestnut, comes into bearing quite young, nuts are fair size and borne in clusters and exceptionally sweet and highly flavored.

Price-35 cents each; three for $\$ 1.00 ; \$ 3.50$ per dozen.

PAWPAW-Golden Gem, tree very ornamental and productive of highly flavored fruit, rich golden color, hardy and bears quite young.

Price-35 cents each; three for $\$ 1.00 ; \$ 3.50$ per dozen.

\section{Shade Trees and Ornamentals}

Silver Maple, Hard Maple, Golden Poplar, White Elm, American:Elm, Silver Linn, White Flowering Dogwood, White Pine, American Pine, Blue Cedar.

Select trees 35 cents; three for $\$ 1.00 ; \$ 3.50$ per dozen.

\section{Shrubbery}

Hydrangea, (P. G.), perfectly hardy, Lilac, American Beauty Rose, Crimson and Baby Ramblers.

35 cents each; three for $\$ 1.00 ; \$ 3.50$ per dozen.

\section{Hardy Ferns}

Maidenhair (Adiantum Pedatum), Royal (Regalis), Cinnamon (Cinnamomea), Christmas Fern, Etc. All retain their fresh verdant greenness through the most severe northern winters; they can not be surpassed for ornamentals and are very easy to transplant.

Price-Extra strong crowns and roots $\$ 1.00$ per dozen; $\$ 5.00$ per $100 ; \$ 15.00$ per $500 ; \$ 25.00$ per 1000 .

\section{BERRY SEEDS}

Owing to the fact that a great many varieties will reproduce more or less true to the seed, and that hundreds are experimenting with planting berry seed, we are offering a choice lot of seed of all the best standard varieties at an extremely low price; all fresh seed from vigorous and healthy stock. 
BLACKBERRY-Gray's Perfection, Ea. Harvest, Snyder, Mersereau, Lovett's Best, Wilson, Etc.

RASPBERRY - Hoosier Black Cap, Cumberland, Plum Farmer, Kansas, Etc. Red Rose, Louden, Miller, Ea. King, Reds.

STRAWBERRY - Dollar Mark, Gandy, Aroma, Dunlap, Haverland, Warfield, Parson's Beauty, Nick Ohmer, Pride of Michigan, Fairfield, Midnight, Etc.

DEWBERRY - Daisy, Lucretia, Austin, Premo, Etc. riety.

Per package of 500 seed, 15 cents; per package 1000 seed, 25 cents; any va-

All quotations made herein are for cash with order. Remit in any way most convenient. Private checks accepted.

Always order real early while all lines are full, and bear in mind that all orders must be filled in "barber shop order," first come, first served.

Yours for a prosperous season,

\section{GRAY'S NURSERY,}

R. D. No. 13, Box 79

PEKIN, INDIANA

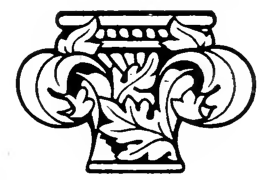




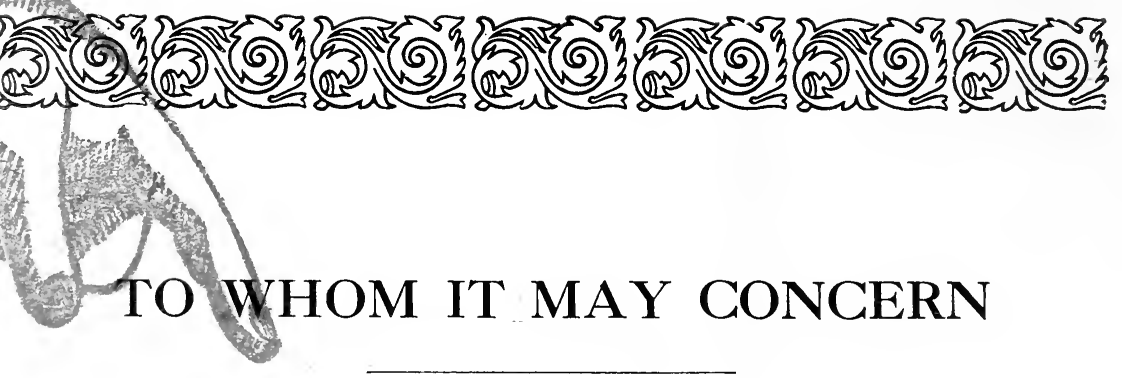

\section{The Fruit Growing Public in Particular:}

We the business men of Pekin, Ind., and of Borden, Ind., most heartily recommend Alvia G. Gray, who is the leading Nurseryman of our locality, growing a full line of all standard varieties of fruit trees and berry plants true to name. Personally we know him to be strictly honest and straightforward and will give every one a "square deal."

He specializes in small fruits, having originated several varieties of berry plants that have given him, as well as this section of the country, a national reputation, as producing the flnest berries in the world.

$$
\text { PEKIN, IND. }
$$

G. M. Johnson, Merchant

A. G. Skiles, Cashier Citizen's Bank

W. L. Green, M. D.

Chas. E. Graves, Postmaster

Roy E. Zink, Merchant

W. L. Sullivan, Merchant

C. B. Elrod, Merchant

J. B. Churchman, Furniture

Thos. Bellows, President Citizen's Bank
BORDEN, IND.

Murray S. Wilson, Cashier Borden State Bank

C. E. McKinley, President Borden State Bank

Jesse E. McKinley, Merchant

A. E. Olmstead, Publisher Clark County Sentinel
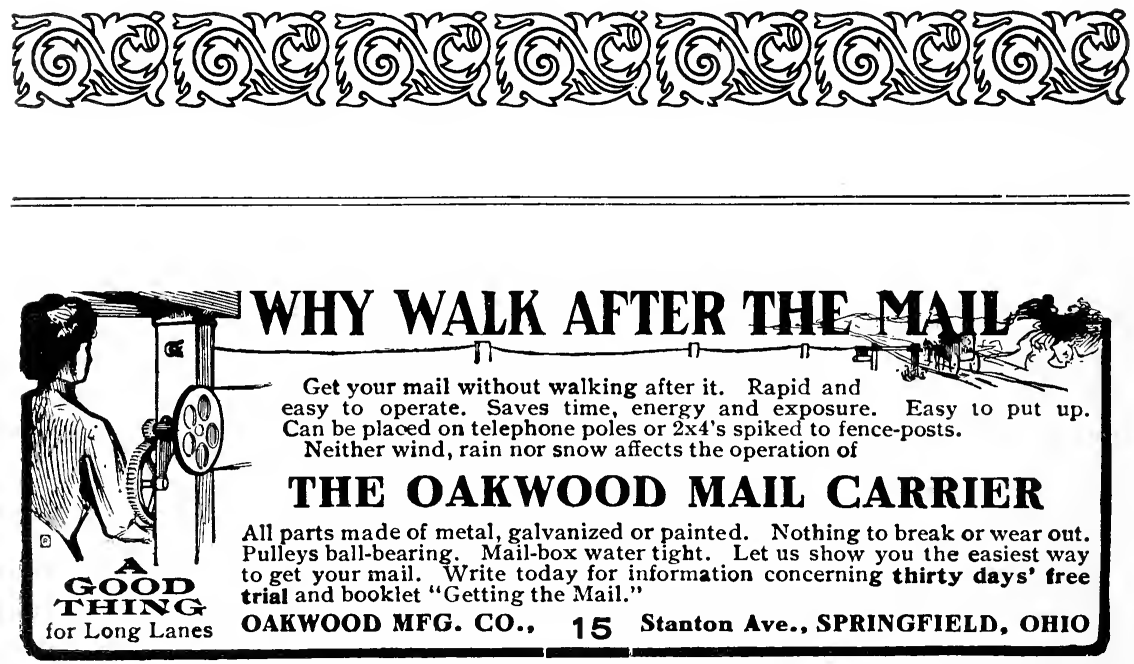

PUBLISHER'S NOTICE-We use this Carrier at one of our fruit farms and recommend it to our customers. 


\section{Durm Tie and Lumber Co. BORDEN, INDIANA}

Dealers In

\section{Railroad Posts, Ties and Timbers}

\section{Also MANUFACTURERS OF ALL KINDS OF LUMBER}

This Company now owns some of the best tracts of timber in Southern Indiana and with their full equipment of the latest improved machinery are in a position to turn out a product second to none.

\section{YOUR PATRONAGE SOLICITED.}

\section{Orchard Insurance}

The 1907 Year Book of the U. S. Department of Agriculture (Page 337) says: "The Beagle is rapidly taking precedence as a favorite for rabbit hunting." All of our horticultural papers and best authorities agree that a rabbit can not stay on the same farm where an English Beagle is kept. Rabbits sometimes destroy a whole orchard or nursery in a single night. If you want to avoid all risk, write us for prices on English Beagle Hounds. 


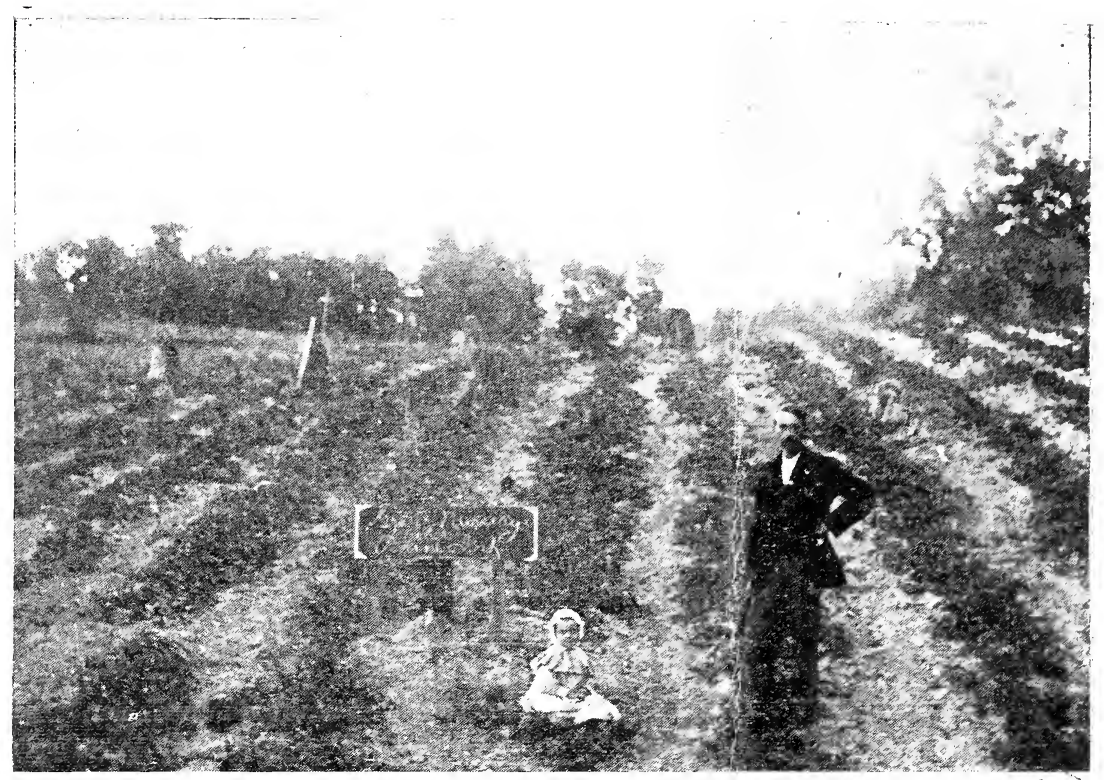

ᄋ듀류

जै

-

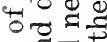

ह त

政记

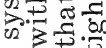

ज

듕

30

ธ

ت્نี

듀 휴

L。

त

0.

ส ํํㅇ

है ㅇํㅇ है.

क $三$ ह

के के

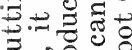

$3+50$

०थ

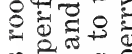

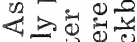

퐁
One of Shrubbery Plant Beds in New Ground. Note Stumps.

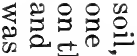

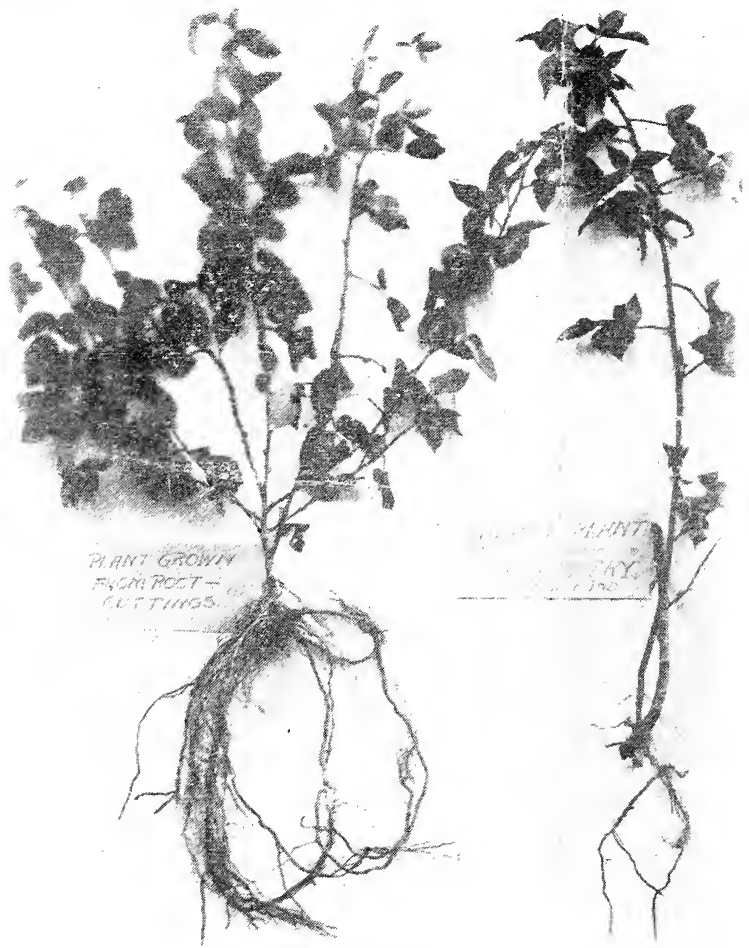

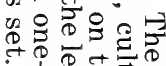

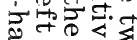

क马

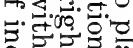

न

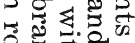

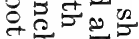

ช

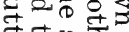

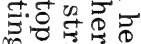
की

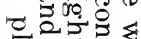

गण

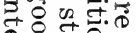

820

कि

乐 ¿ 8

कथ कै

की

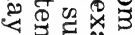

专々

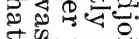

5

1 20

है

을 8

0 年

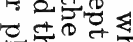

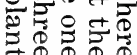




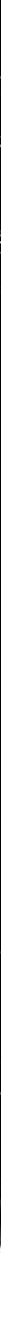

Wholesale catalogue and price list : fruit trees, berry plants, cuttings, etc. Gray's Nursery. 
